\title{
Conjugalidade e profissão de modelo: projetos conflitantes ou complementares?*
}

\author{
Rita de Cássia Pereira Farias ${ }^{* *}$
}

\section{Resumo}

Este artigo analisa um grupo de pré-adolescentes pobres do interior mineiro que frequentaram um Curso de Modelo. Face ao apelo erótico que envolve, na mídia, a imagem dessa profissão, parece paradoxal que os pais - que associam esta carreira à prostituição - matriculem as filhas em tal curso, em aparente conflito com sua moral familiar e religiosa. O curso permite a aquisição de habilidades e o domínio de códigos que não pertencem a sua condição de classe. Além disso, participar do curso e desfilar em ambientes frequentados pela elite se tornam estratégias de apresentar a filha à sociedade, ampliando o capital social familiar.

Palavras-chave: Profissão de Modelo, Pré-Adolescentes, Moral Familiar Religiosa

\footnotetext{
* Recebido para publicação em fevereiro de 2008, aceito em outubro de 2009. Este trabalho faz parte da minha dissertação de mestrado (Nos bastidores da moda: um estudo sobre representações de vestuário e de imagem corporal por um grupo de pré-adolescentes). Agradeço a Heloisa Pontes pela sugestão de publicar o artigo, pela leitura cuidadosa do texto original e pertinentes sugestões que o enriqueceram.

** Professora da UFV, doutoranda em Antropologia, Unicamp. farias.rcp@gmail.com
} 
Marriage and Model Profession:

Conflicting or Complementary Projects?

\begin{abstract}
This paper analyses a group of poor pre-adolescents in a modeling course in Minas Gerais. Facing the erotic image of the profession, presented by the media, it seems paradoxical that the parents who associate this career with prostitution - register the daughters in such a course, in apparent conflict with the family's religious morals. The course allows the acquisition of abilities and codes which do not belong to the family' class condition. However, to participate in it and to model in events attended by the elite become a strategy to present the daughters to the society, enlarging the family's social capital.
\end{abstract}

Key Words: Model Profession, Pre-Adolescents, Family's Religious Moral 


\section{Modelo e manequim: uma profissão que seduz e encanta}

Em nossa sociedade, a imagem das modelos tem sido divulgada na mídia como um espetáculo a ser idolatrado por ambos os sexos. As estratégias empregadas pela publicidade $e$ pelas agências de modelo associam a imagem das top-models aos últimos recursos tecnológicos para seduzir o espectador. Essa estratégia, ao mesmo tempo em que transmite os ideais contemporâneos de beleza, cria fortes estereótipos quanto ao papel feminino (Almeida, 2001). As construções de gênero pela mídia têm sido contraditórias, pois as mulheres são representadas ora como dóceis, frágeis, submissas e dedicadas ao lar, ao marido $e$ aos filhos, outras vezes a imagem feminina é revestida de um forte apelo à sensualidade e ao erotismo. $\mathrm{O}$ contato com essas imagens facilita a incorporação desses marcadores, contribuindo para que a profissão de modelo seja admirada e desejada, ao mesmo tempo em que é temida por aqueles que prezam os valores ligados ao pudor, pois frequentemente a vida das modelos é envolvida em "escândalos" e "exageros".

A profissão de modelo, que veio, mais tarde, a tornar-se um fenômeno, teve início no Brasil no final da década de 1940, quando as casas de moda passaram a utilizar jovens como "manequins vivos" para mostrar trajes a seus clientes (Bonadio, 2004). Naquela época, a expressão e profissão de "manequim $e$ modelo" mal existiam. Era apenas o início de algo que só se tornaria, mais tarde, um fenômeno. Não existiam os flashes e o glamour da profissão, conforme acontece nos dias atuais. Nas últimas décadas há uma penetração, no País, de agências internacionais que visam selecionar novas modelos, cuja escolha vem recaindo sobre jovens em idades cada vez menores. Como a indústria da beleza busca estimular o culto ao corpo e a exaltação da juventude, as agências de modelo têm feito apelo para meninas que ainda não entraram na adolescência, pois na fase em que se encontram seus corpos são facilmente "educados" $e$ "moldados" para construir o "modelo de beleza". 
Devido ao seu glamour, essa profissão não é almejada somente por mulheres adultas, mas também por adolescentes $e$ crianças que, mesmo não tendo fonte própria de renda, desejam e consomem os efêmeros e, muitas vezes, extravagantes produtos do mundo da moda. Além disso, disputam, por meio do corpo e da moda, status, prestígio e até mesmo a possibilidade de uma mobilidade social para si e para a família. Essa apropriação muitas vezes se dá por indivíduos pertencentes a universos muito distantes daquele das top-models, como as pré-adolescentes pobres residentes no interior mineiro, sujeitos de estudo desta pesquisa.

Visando apreender algumas influências que o fenômeno das modelos exerce sobre pessoas que se encontram espacial $e$ socialmente distantes das grandes plataformas de lançamento da moda, o universo pesquisado foi constituído por dez préadolescentes do sexo feminino com idades entre 9 e 12 anos, que frequentaram um curso de modelo e manequim na cidade de Viçosa, MG. Das pré-adolescentes pesquisadas, sete eram provenientes de famílias cuja renda familiar era inferior a cinco salários mínimos. Cinco residiam na periferia pobre e três residiam em locais menos prestigiados do centro da cidade. Apenas um pai e duas mães possuíam curso superior. Cinco estudavam em escola pública e todas afirmaram ser católicas, sendo que oito delas participavam de catequese.

O contato dessas meninas com a mídia, via televisão $e$ revistas, permite que o glamouroso universo das modelos, detentor de grande prestígio, seduza e desperte as préadolescentes para uma apropriação do estilo de vida das estrelas que aparecem na mídia, em busca de similaridade e integração. Conforme Meyrowitz (1986), a mídia eletrônica sobrepõe áreas que parecem distintas e proporciona uma ampliação do leque de informações dos espectadores, permitindo acesso a lugares $e$ situações muitas vezes inacessíveis na vida cotidiana, tornando-os familiar. Assim, o local social do espectador deixa de ser sua única referência. 
A participação das pré-adolescentes no curso de manequim e modelo é motivada, principalmente, pelos mitos presentes nos cenários midiáticos da beleza e da moda. As roupas bonitas, viagens, festas "badaladas", reconhecimento social, dinheiro, admiração, destaque, aplausos, autógrafos, camarins, "boa vida", "ter tudo o que gosta", fama e prestígio são mencionados como as principais razões que levam as pré-adolescentes a tentar trabalhar como modelo. Esse sonho as acompanha desde a mais tenra idade, pois, já nos primeiros anos de vida são expostas $e$ habituadas a um conjunto de imagens, que exaltam a beleza, o corpo e o sucesso. Todas as pré-adolescentes afirmaram que "sempre" gostaram de ver televisão. "Sempre" quiseram ser modelos. "Sempre" gostaram de fazer poses para fotos, desfilar, dançar e cantar. As imagens, apresentadas na televisão, levam a uma naturalização do desejo da beleza e do sucesso, como ressalta Amanda:

Eu sempre gostei muito de ver televisão. Aí eu via as atrizes e modelos desfilando e falava: Nossa! Um dia eu quero ser modelo, eu quero desfilar na passarela eu quero... assim... ser uma miss Brasil.

As pré-adolescentes espelham-se nas modelos em função do ícone que representam: ter e ser. Seus sonhos apontam para o desejo de consumo, bem como para a necessidade social de prestígio e reconhecimento, em oposição a uma vida de restrições econômicas e ocultamento social. As imagens das modelos na mídia exercem fascínio e encanto sobre as pré-adolescentes. Afinal, a publicidade produz um mundo idealizado, onde tudo é organizado para compor um quadro mágico de "felicidade absoluta e impossível. Onde não habitam a dor, a miséria, a angústia, a questão", como ressalta Everardo Rocha (1995:25).

Exaltando um ideal de beleza e riqueza, a mídia $e$ as agências apresentam a profissão de modelo como algo altamente convidativo, uma possibilidade ao alcance de todos. Diante dos 
atraentes anúncios, ter a profissão de manequim e modelo parece algo fácil de ser alcançado e sem muitos fatores limitantes. Assim, ao assistirem a algum desfile de modas ou tomar conhecimento sobre o oferecimento do curso de manequim e modelo, as préadolescentes imaginam que é possível se tornarem uma das manequins famosas apresentadas na mídia, como menciona Bárbara:

meu sonho é tornar uma modelo famosa de televisão. Eu me imagino viajando para vários lugares... as pessoas me parando na rua, me pedindo autógrafo... ser uma modelo de televisão conhecida, tipo (...) Daniela Cicarelli.

A faixa etária delimitada, a possibilidade de trabalhar, inicialmente, em sua cidade $e$ a possibilidade de fama $e$ mobilidade social favorecem a participação das pré-adolescentes no curso de modelo. A oportunidade de frequentar o curso $e$ desfilar nas passarelas da cidade é muito gratificante para essas meninas, pois proporciona a ilusão de estar participando do elitizado grupo das top-models apresentadas na mídia, como ressalta Helena: "É uma coisa muito boa, não tem coisa melhor. $\mathrm{Na}$ hora que você está desfilando, todo mundo te olhando $e$ aplaudindo parece que seus sonhos estão sendo realizados". Durante o desfile, ao serem destacadas, admiradas, fotografadas e aplaudidas diante de um público, elas se sentem parte do universo das modelos famosas, como expressa Amanda "Foi uma sensação muito boa, eu me senti a própria Gisele Bündchen ${ }^{1} \ldots$ toda poderosa".

Além do sucesso, as agências prometem às modelos a possibilidade de se tornarem milionárias. Assim, as préadolescentes têm a ilusão de que podem se inserir nessa profissão e obter êxito e sucesso, caso elas se empenhem, como acredita Denise: "se eu tentar, passar em várias agências, correr atrás, eu

1 Modelo brasileira mais bem paga e de maior sucesso no país e no exterior na ocasião da pesquisa. 
posso me tornar uma profissional um dia, porque todas as profissionais passaram por estas mesmas etapas".

O encantamento das pré-adolescentes com o mundo das modelos desperta para a possibilidade de obter fama e sucesso, o que as fascina. Entretanto, elas são confrontadas com diversas limitações, como será destacado a seguir.

\section{O sonho de tornar-se manequim e modelo: entre realizações e decepções}

Como o investimento no curso de manequim e modelo em Viçosa é acessível à realidade das famílias ${ }^{2}$ e não há pré-requisitos para fazê-lo, esse sonho, a princípio, parece fácil de ser concretizado. Assim, as pré-adolescentes almejam se tornarem famosas e reconhecidas. As representações e expectativas em relação ao curso variavam conforme o status socioeconômico das famílias. Os depoimentos comprovam que cinco famílias com melhor status socioeconômico não alimentavam muita esperança em torno do curso, pois tinham uma visão mais realista da profissão. Entendiam que é uma profissão difícil, muito concorrida, que exige muita dedicação e muita renúncia em termos de família, namoro e lazer, além de oferecer poucas perspectivas de futuro. Os pais com essa visão motivavam as filhas a participar do curso como uma atividade lúdica ou recreativa, como também uma forma de se aprender "algo mais" para ser utilizado no decorrer da vida, como boa postura e regras de etiqueta. A mãe da lasmim mencionou que quando sua filha quis fazer o curso ela disse:

Não precisa você querer continuar que não é uma coisa que a gente vai trabalhar em cima disso. Fez por fazer. Fez

${ }^{2} \mathrm{Na}$ ocasião da pesquisa, o valor do curso era de $\mathrm{R} \$ 40,00$ (aproximadamente $15,38 \%$ do salário mínimo). Em alguns casos, o curso era custeado por uma tia ou outro parente. 
mais pra aprender Acho que de tudo se tira alguma coisa boa pra ser aproveitada na vida.

Das cinco famílias que possuíam menor status socioeconômico, três demonstraram alimentar uma possibilidade de mobilidade social. A participação no curso é sentida como expectativa ou esperança de obter um futuro melhor. As manequins $e$ as modelos de sucesso representam a possibilidade concreta de atingir uma posição social de semelhante status. Os depoimentos e o perfil sociocultural de três famílias (baixa escolaridade dos pais, baixa remuneração, profissão pouco prestigiosa e residência na periferia pobre da cidade $)^{3}$ revelam que a participação no curso de modelo faz parte de um projeto das mães, não das filhas. Em certa medida, as filhas aprendem a gostar da idéia de ser modelo, em função do envolvimento, interesse e sonhos da mãe, já que a participação no curso e nos desfiles lhes rendia maior popularidade, pois possibilitava tornarse conhecida por várias pessoas. Além disso, elas aprendiam maneiras de se vestir "melhor" e de se portar em restaurantes $e$ eventos sociais.

Embora desejassem investir na carreira da filha, duas mães afirmaram não ter condições para tal. Já a mãe de Eliana ${ }^{4}$, embora possuísse baixa renda, procurava investir na aparência $e$ promoção da filha como uma tentativa de reconhecimento, projeção e ascensão social. Ela se esforçava para que a filha participasse dos desfiles e procurava comprar roupas nas melhores lojas da cidade, usando quase todo o seu rendimento como doméstica, conforme ela mesma afirmou:

3 Essas meninas estudavam em escolas públicas, moravam na periferia pobre, tinham renda familiar entre um a cinco salários mínimos, duas mães eram empregadas domésticas e os pais vigilantes de condomínio, uma era enfermeira auxiliar e o pai motorista da prefeitura.

4 Empregada doméstica e o marido é porteiro de prédio, cuja renda mensal era de dois salários mínimos. 
Antes de colocar ela [no curso], ela não tinha interesse não. Era mais eu mesma que tinha interesse. Assim que eu a coloquei, ela passou a ter interesse em ser modelo. Eu a coloquei mais pra fazer esse curso porque todo mundo comentava que ela era muito bonita. (...) Eu queria que ela participasse de um desfile em $\mathrm{BH}$ que tem vários prêmios também, entendeu? Mas quando eu fiquei sabendo já estava muito em cima da hora e não dava mais tempo. Mas quando aparecer uma outra oportunidade, eu tenho coragem de levar ela. O prêmio é 3.000 em dinheiro e 3.000 em prêmios. Então eu a coloco pra desfilar porque de repente alguém pode a ver desfilando e gostar. (...) Tem a grana também que é muito boa, conhecer outros países, essas coisas assim (mãe de Eliana, empregada doméstica).

Como os grandes eventos de moda e beleza acontecem nos grandes centros e os pais das pré-adolescentes não podiam acompanhá-las, essas meninas, por ocupar posição de classe menos prestigiosa, participavam com desigual motivação $e$ menores oportunidades. Alguns depoimentos evidenciam como as pré-adolescentes e seus familiares interpretavam e reagiam a essa realidade:

Quando aparece algum trabalho eu falo, mãe, olha lá, tem esse trabalho, quero fazer isso, mas a minha mãe diz: Não é aqui na cidade. Aí eu falo assim: Mãe, mas meu pai me leva, meu pai conhece vários lugares, deixa eu ir! Então minha mãe fica me olhando assim e fala: Tá bom, então a gente vai ver. Eu falei com meu pai: Pai tem o concurso Talentos Brilhantes lá em Juiz de Fora, aí meu pai falou: Então vamos, mas aí minha mãe não deixou porque não podia me levar... Meu pai gosta, sabe, de me ver evoluir (Amanda, 12 anos).

Pra ir pra frente, teria que acompanhar a Amanda. Eu não posso e meu marido não pode. Então ficou do jeito que tá, né? Eu tenho medo, sozinha eu não deixo. Vai depender da pessoa que puder acompanhar, né? (mãe de Amanda, 36 anos, auxiliar de enfermagem). 
A diferença entre o universo social das modelos e o das meninas demonstra grande discrepância entre os sonhos "vendidos" pela mídia e a realidade das pré-adolescentes interioranas de baixo poder aquisitivo. Embora haja uma naturalização do desejo de ser modelo, as possibilidades concretas de realizá-lo são ínfimas. As barreiras mais evidentes que separam os dois mundos referem-se à questão econômica, que não permite sequer fazer um book - embora todas as pré-adolescentes tenham demonstrado interesse em fazer o book, apenas três conseguiram ou mesmo a obtenção de roupas da moda, quando são lançadas. Essa aquisição é feita somente de forma tardia, quando a moda já foi bastante propagada e os preços reduzidos, como expressa Cíntia:

Tem umas [roupas da moda] assim, que é mais difícil, as mais cara, assim... mas, tem umas que eu consigo. [Amanda também comenta] Quando uma roupa que me interessa está no auge eu geralmente não consigo comprar. É incrível! Quando ela está estourando eu não consigo comprar não. Quando ela vai passando assim, eu consigo.

Além das barreiras econômicas, o corpo se coloca como um fator limitante, já que a maioria das participantes não se enquadra nos padrões de beleza vigentes. Para ser modelo de passarela, é fundamental ter corpo magro e longilíneo (estatura superior a 1,70). Ao selecionar uma modelo, as agências levam em conta vários fatores - harmonia do rosto (nariz, boca, orelha, maçã do rosto, pescoço, cabelo, olhos) e também o tipo de pele (cor, textura, suavidade). Já a modelo fotográfica não precisa ser necessariamente alta, mas é necessário ter uma boa expressão corporal. Informadas no curso sobre o biotipo exigido pelas agências, as pré-adolescentes aprendem a encontrar "defeitos" em seus corpos, como ressalta Helena: 
Pra eu me achar bonita eu teria que mudar o meu cabelo assim, ser mais liso [ela tem cabelo crespo]. Eu precisava ter mais corpo, ou seja, mais peito e bunda. [Amanda também comenta] se pudesse mudar alguma coisa no meu corpo tiraria minhas estrias, acnes. Meu cotovelo e joelho são muito feios... Acho meus pés horríveis e meu nariz, acho o meu nariz meio... tipo, nariz de bolinha. Eu não gosto muito dele.

A professora do curso comenta sobre um concurso de beleza infantil em que havia uma menina "gordinha", que

tinha uma "presença na passarela" e desfilava muito bem. Uma pena que ela é bem gordinha, isso, com certeza, não tem jeito de ganhar, porque um dos quesitos avaliados é a beleza plástica, que é justamente você ter um corpo proporcional à sua altura, além de ter desenvoltura. Então ela perde.

Também é reforçada a importância dos cabelos lisos, já que a professora aconselha que as meninas estejam sempre com os cabelos escovados. Com isso, as cinco pré-adolescentes que tinham os cabelos crespos ou anelados manifestaram o desejo de tê-los lisos. Expostas a um ideal coercitivo, que privilegia que o corpo "perfeito", ou seja, alto, magro e com cabelos lisos, as préadolescentes ficam insatisfeitas com o próprio corpo. Assim, logo no início da tentativa de inserção na carreira de modelo, surgem as primeiras contradições que serão acompanhadas por várias outras.

As pré-adolescentes que alimentaram maiores ilusões quanto ao curso e que mais se envolveram foram as que mais sofreram e se decepcionaram, como Amanda, que participou de um concurso de beleza e ficou em último lugar: "me deixou muito triste e abatida, porque vencer era o meu grande sonho". Os depoimentos de Helena e Amanda evidenciam que a participação no curso conferiu segurança para que elas se inscrevessem em 
concursos de beleza. Como o mundo da moda busca beleza exótica, elas entendiam que, para ser manequim e vencer concursos, não é preciso ser muito bonita, pois o segredo está em "dominar a passarela". Assim, participaram de concursos acreditando que, por terem feito o curso, iriam vencer. No entanto, a realidade revelou-se muito diferente de seus sonhos $e$ percepções, trazendo o receio de perdas futuras, como ressalta Helena:

Você pode ser a menina mais feia assim, sabe? E conseguir ganhar um título, assim, por exemplo, se ela não for tão bonita, entendeu? Tão linda, mas se ela desfilar melhor, saber desfilar e a outra não, acho que a outra não vai ganhar só porque ela é mais bonita, entendeu? (...) Eu pensei que era só fazer o curso que logo eu ia ganhar vários concursos, que o primeiro concurso que eu fizesse eu ia ganhar. Eu achava muito bonito ganhar, todo mundo te aplaudir, ser conhecida. Aí, logo que fiz o curso eu participei de um concurso chamado Garota Castor, não passei, aí eu chorei demais. (...) Eu tenho muito medo de perder de novo, foi muito ruim, sabe? Depois que eu cresci um pouco... que eu comecei a ler as coisas, assim, eu fiquei vendo que era um pouco fantasia, que tava muito longe do que eu imaginava. Sabe, que tem certas dificuldades como todo muito tem, entendeu? Dinheiro não é tudo, sabe, dinheiro ajuda, mas não traz felicidade. Traz felicidade só por um momento e depois não traz felicidade. Na vida das pessoas famosas, não adianta nada você ser rica, tipo todo mundo te conhecer, esses negócios, parecer pros outros que você é feliz, mas você chegar em casa e tem uma coisa que te deixa triste, entendeu? Ser feliz só pros outros.

Não vencer o concurso parece ser a primeira grande desilusão na vida dessas pré-adolescentes. A "falta de beleza", que antes não incomodava, passa agora a incomodar. O medo de perder outros concursos (e quem sabe, a perda em outros setores da vida por não corresponder aos padrões de beleza) pode estar 
associado ao caráter subjetivo do julgamento. Além da beleza, é exigido que a vencedora tenha uma "presença na passarela", que "domine a passarela". Mas, afinal, como se adquire essa competência, essa "presença", esse domínio, uma vez que tal prerrogativa não pode ser ensinada no curso? Como ressalta a própria professora:

A menina que ganhou o concurso desfilava tão bem! Tinha uma tranquilidade na passarela, um andarzinho direitinho... tinha uma presença na passarela... Na hora que entra na passarela, ela tem uma postura, um carisma... um tchan, sabe? Ela entra, domina a passarela e te prende a atenção!.

O curso de modelo é um tipo de pedagogia cultural (Silva, 1985) que ensina as meninas a compararem o seu próprio corpo com o "ideal de beleza" e, desde cedo, se sentirem "inadequadas", "feias", inferiorizadas e insatisfeitas com o seu corpo, além de encorajar a competitividade negativa entre as mulheres. O curso de modelo acaba se configurando como "discursos regulatórios que formam o sujeito" (Butler, 2005:9), os quais fazem parte de um poder regulatório maior que opera sobre o gênero, produzindo e naturalizando noções de masculino $e$ feminino. Embora o corpo feminino tenha se emancipado de suas antigas servidões (sexuais, procriadoras e indumentárias), Mirian Goldenberg (2006) menciona que ele se encontra submetido a coerções estéticas mais imperativas e mais geradoras de ansiedade que antigamente, exigindo um alto grau de controle sobre o corpo e a aparência.

$\mathrm{O}$ alto investimento na imagem corporal, o que Naomi Wolf denominou $O$ mito da beleza, iniciou após a Revolução Industrial, quando as mulheres se libertaram da mística da feminilidade. A busca incessante pela beleza foi uma forma de transferir o controle social do doméstico para a beleza, afinal, é um mito que "determina o comportamento e não a aparência" (Wolf, 1991:17). Diante da coerção da "beleza", a autora acredita que o mito da 
beleza é a única trincheira ainda a ser derrubada para que as mulheres obtenham a tão almejada igualdade. Como não existe nada de "objetivo" em relação à beleza, na visão de Wolf, o concurso de beleza é uma forma pública de destituir alguém de sua beleza. Fazer isso na presença de várias testemunhas "equivale a convidar todos os olhos a confirmarem sua feiúra, (...) o que proporciona um espetáculo degradante contra a mulher" (Id. ib.:47).

Após a realização do curso, as pré-adolescentes ficaram na expectativa de serem chamadas para fazer algum trabalho com a professora, como o de panfletagem ou de recepcionista em eventos. No entanto, a preferência é dada para as mais "experientes", devido à responsabilidade e ao compromisso que o trabalho exige. Além disso, quando surge um trabalho, é necessário "encaixar" a pessoa certa no perfil exigido pela empresa contratante. Para evitar maiores conflitos, a professora pede às meninas para não ficarem chateadas por ela indicar outra pessoa que tem o perfil adequado ao trabalho exigido. Embora entendam a situação, as meninas se queixam de nunca terem sido "encaixadas". Nenhuma pré-adolescente afirmou ter sido convidada para fazer algum trabalho como manequim ou modelo.

Apesar de todas elas e suas famílias terem ficado satisfeitas com os conteúdos transmitidos no curso, cinco pré-adolescentes e suas mães, que viam no curso um canal de inserção para a profissão de modelo, ficaram decepcionadas, pois esperavam obter benefícios, como maiores oportunidades de desfile, convites para trabalhos e reconhecimento social. Tanto as mães quanto as pré-adolescentes reclamaram que em Viçosa eram oferecidas poucas oportunidades para as modelos. Poucos desfiles eram realizados e, quando ocorriam, a família tinha que pagar para a filha desfilar. Assim, lamentaram que, ao invés de retorno, só havia despesas. As famílias mais realistas com relação à profissão, por sua vez, afirmaram que o curso correspondeu, ou até mesmo superou, suas expectativas. Uma mãe disse que esperava que o 
envolvimento da filha no curso fosse apenas uma "brincadeira de criança".

Em função das exigências relativas à carreira de modelo, da alta seletividade no ramo, devido ao reduzido número de vagas nos eventos ligados à beleza e à moda e das dificuldades enfrentadas pelas pré-adolescentes, a professora do curso desempenha um papel meio dúbio. Ao mesmo tempo em que faz apelo aos sonhos e fantasias, sabe que, possivelmente, suas alunas não chegarão a entrar no mundo da fama, por isso ressalta a seletividade da profissão, visando minimizar conflitos. Ela afirma não ser fácil a inserção na carreira, pois se trata de uma profissão que exige muita dedicação e que o curso não garante a atuação profissional. A mãe de Fabíola ressalta esse aspecto:

A Isabella [professora do curso] explicou que é uma coisa que não ganha dinheiro, sabe? Quando ganha alguma coisa, no máximo, é um presentinho bobinho. E tem a desvantagem de ter que ficar vendendo ingresso, pagando pra desfilar... essas coisas assim...

A não-atuação na profissão de manequim e modelo levou as pré-adolescentes a entender que o curso era muito básico e que ainda havia muito para ser aprendido. Todas afirmaram ter interesse em continuar participando de novos cursos, a fim de adquirir a competência necessária para inserir-se na tão almejada profissão. Embora almejassem investir em seus sonhos, as préadolescentes e suas famílias sabiam das limitações decorrentes de seu biótipo e de sua condição de classe. Ao mesmo tempo em que esperavam grande retorno, afirmam que, por ser um curso básico, suas expectativas não eram muito elevadas.

Tanto as pré-adolescentes quanto suas famílias estavam conscientes de que para ter sucesso na profissão de modelo era preciso "correr atrás", o que se tornava difícil dentro de suas realidades. Para que o curso de manequim e modelo constitua em elemento propiciador da mobilidade social, não basta participar 
de atividades esporádicas e isoladas, é necessária uma inserção nos canais de promoção social, como a participação nos grandes eventos que acontecem nas regióes metropolitanas. Trata-se de um investimento na promoção da auto-imagem que envolve tempo, dinheiro, determinação, viagens, books, roupas bonitas, contatos, etc., os quais estão muito além das possibilidades das famílias pesquisadas.

Frequentar um curso de manequim pode representar o início de uma nova fase de destaque social para as préadolescentes. No entanto, com o passar do tempo, elas acabam se deparando com uma série de limitações materiais, humanas e financeiras. Há um misto de sonho, esperança e realidade. Ao mesmo tempo em que elas acreditam nas diversas possibilidades que poderão surgir caso "corram atrás" da profissão de modelo, as limitações impostas pelo alto investimento em tempo $e$ dinheiro, localização do mercado em São Paulo, entre outros, revelam o distanciamento entre o sonho e a realidade. Além desses entraves, a corporalidade erotizada, muitas vezes exigida para possíveis trabalhos publicitários, demonstra uma incompatibilidade entre os valores familiares e aqueles veiculados pelas modelos apresentadas na mídia.

As mães disseram que achavam bonitos os desfiles $e$ as manequins apresentadas na televisão e nas revistas de moda. Por isso, permitiam a participação das filhas no curso e até mesmo chegavam a almejar que fizessem sucesso. Entretanto, devido ao fato de muitas modelos famosas terem suas vidas envolvidas em "escândalos", a possibilidade de ingressar nessa profissão traz alguns conflitos para as famílias que precisam ser equilibrados com a moralidade familiar.

\section{Sobre a moralidade familiar}

Independentemente do nível de escolaridade ou renda, algumas famílias pesquisadas consideravam as artistas muito vulgares porque "não se valorizam", "se envolvem com 
prostituição" e "vendem" o corpo para "subir na vida". Em razão dessas representações, quando os pais tomavam conhecimento sobre o curso, procuravam logo saber do que se tratava para não correr o risco de ver a filha envolvida com nada que contrariasse seus princípios. Por conta dessa moral, as famílias só concordavam com fotos em que a nudez não era exposta. As cenas das modelos, em que o corpo era parcialmente exposto $e$ que não se referiam ao erotismo e sensualidade, eram toleradas. Um exemplo disso é o uso de biquínis e roupas curtas e cavadas, apresentadas nas revistas de moda. Já as fotos nuas, com apelo erótico (como nas revistas masculinas) eram rejeitadas, como revela o depoimento de uma das mães:

Eu acho que uma modelo não tem que posar nua, não está dentro da profissão. Ela não vai fazer isso porque ela é modelo, ela vai fazer isso pra ganhar dinheiro. Agora eu não tenho nada contra desfilar de biquíni, né, uma roupa cavada, curta, eu acho normal. Agora, posar nua, nem sempre é só a modelo que faz isso. Em outras profissões tem aquelas que têm um corpo bonito que fazem isso. Eu sou contra posar nua. A pessoa faz isso pela grana. Eu não sou muito a favor daquilo que você faz exclusivamente pela grana, não. Tem que ser meio assim: o prazer com o dinheiro, né? O fazer só pelo prazer, não (mãe da Helena, 43 anos, curso superior em Matemática, professora de escola pública).

Os argumentos das mães demonstram forte conotação moral e, conforme Silva (1985:12), "uma tensão entre os dois projetos de vida: ser esposa e profissional". Em função dessa tensão, a opinião das mães em relação às modelos envolve um processo de valorização e críticas. Valorizam-nas em função de sua beleza, prestígio, fama, reconhecimento e dinheiro; $e$ desvalorizam-nas devido à "vulgaridade", ao "erotismo", à "falta de pudor" e à "prostituição". Os relatos demonstram que as representações dessa profissão conjugam o glamour e a fantasia 
com os preconceitos que perpetuam desde a sua introdução no Brasil, em 1940, época em que a profissão envolvia uma pesada carga de preconceito social. Conforme Claudia Bonadio (2004:77), "a publicidade de moda transforma a imagem corporal das modelos em capital, em objeto de consumo e mercadoria, o que acaba por associá-las à prostituição". As primeiras modelos ocupavam "uma posição complexa, repleta de conflitos morais e de difícil aceitação social" (Id. ib.:64), pois tinham fama de que eram "putas", mulheres "fáceis", "transgressoras do sistema prescritivo cultural dominante" (Id. ib.:77).

A vinculação da imagem das modelos com a prostituição deve-se ao uso da nudez feminina para vender produtos, que se tornou frequente, segundo Naomi Wolf (1991), principalmente, a partir de 1980, ocasião em que o feminismo encontra-se mais fortalecido. Além de recorrer ao corpo feminino para impor um ideal de beleza e vender produtos e estilos de vida, os publicitários recorrem à nudez feminina para que a imagem cause impacto, "seja porque estão colocadas fora de contexto ou porque desafiam as normas vigentes", ressalta Iara Beleli. Na visão da autora, a propaganda orienta modos de ser e de viver, em que persuadir é sinônimo de seduzir e "a erotização passa pelo corpo da mulher $e$ pelo desejo do homem" o que contribui para reificar noções de gênero, sexualidade e desejo (Beleli, 2007:211).

Naomi Wolf defende que a publicidade não apresenta homens nus para que eles não venham a se examinar e se comparar com outros homens, mantendo sua auto-estima elevada. A preservação da imagem masculina é uma forma de proteger os homens e tornar as mulheres vulneráveis, tornando mais eficazes as pedagogias culturais. Wolf ressalta que essa associação imagética entre pornografia e prostituição é uma forma de abalar a confiança das mulheres em si próprias e deixá-las inseguras, enfraquecendo-as na luta em busca de seus direitos.

Devido à maneira como o corpo feminino é abordado na mídia, ao mesmo tempo em que a profissão de modelo é vista como bonita, glamourosa, prestigiosa, razões pelas quais é 
apreciada, as expressões "andar com o diretor", "mexer com prostituição" e "usar roupas indecentes" revelam uma rejeição por parte das famílias em estudo. Embora haja modelos que sejam tão empenhadas quanto elas na valorização da família, existem modelos e artistas que se deixam fotografar nuas e têm suas vidas frequentemente envolvidas em "escândalos". Entretanto, como não existe uma linha que delimita os comportamentos aceitáveis e reprováveis, para que não haja dúvidas, os pais preferem se cercar de todas as precauções. Em certa medida, mesmo diante da forte influência da mídia, eles se esforçam para preservar nas filhas os valores que privilegiam.

A forma como a televisão enfoca a vida das top-models e a distância entre o padrão moral apresentado na mídia e o contexto em que vivem as famílias permitem que as meninas avaliem o que é desejável ou não para elas e suas famílias. Ao mesmo tempo em que criticam os conteúdos televisivos, as famílias das préadolescentes, candidatas a manequim e modelo, avaliam a forma como essas profissionais são apresentadas na mídia, bem como os prós e contras dessa exposição. Além disso, elas revêem seus valores e opiniões, usando a mídia como moldura para a sua realidade, pois permite avaliar o que combina ou não com a realidade local, como destacado no depoimento a mãe de Amanda:

Modelo, pra mostrar uma roupa para uma revista, pras pessoas copiarem, aí tudo bem, né, agora, do jeito que elas estão fazendo na televisão é muito vulgar. (...) O que dá a entender, de acordo com o que a gente vê na televisão, é que pra pessoa ser famosa... tem que andar com o diretor, tem que andar com fulano $e$ isso eu não gostaria não, entendeu? (...) pra pessoa conseguir ser famosa, ter o nome na mídia, tem que mexer com prostituição. Quando não tem droga no meio.

A conotação moral presente nos argumentos das préadolescentes $e$ de suas mães, que qualificam certas modelos $e$ 
artistas como "vulgares" - aquelas que não se valorizam e expõem seus corpos em demasia -, revela forte preocupação com a reputação familiar. Ao falar sobre as estrelas da mídia, incluindo as modelos, algumas pré-adolescentes e suas mães relacionam a profissão de modelo com a prostituição. Nesse sentido, o que leva os pais a permitirem a participação das filhas no curso de modelo? A resposta requer considerar a moralidade no contexto da vizinhança, bem como a importância do casamento para essas famílias.

\section{As redes de sociabilidade e os sonhos quanto ao casamento}

Viçosa, local onde a pesquisa foi realizada, é uma cidade de pequeno porte, onde as redes de sociabilidade são muito próximas e permeadas por forte moral sexual. Como residem em um local onde todos na vizinhança se conhecem, a privacidade é extremamente reduzida e o anonimato quase impossível. Segundo depoimento de alguns participantes, os vizinhos controlam a vida dos outros com a fofoca, o que pode colocar a moral familiar em risco. Elias e Scotson (2000) ressaltam que os comentários funcionam como um tipo de sanção, à medida que encerram uma acusação de fugir de certos padrões de comportamento, o que pode colocar a moral em suspeita. Assim, a estigmatização de um grupo sobre outro, via fofoca, constitui um eficiente mecanismo de controle, manutenção dos costumes e coesão social. ${ }^{5}$

5 Em Winston Parva, nome fictício dado ao local estudado por Elias e Scotson, havia um grupo de moradores antigos que compartilham por muito tempo de uma tradição bastante concisa e que conservavam um estilo de vida em comum, transmitidos de geração em geração, além de serem envolvidos por laços de intimidade emocional, que garantiam a coesão do grupo. Com o tempo, mudaram-se para essa comunidade várias pessoas vindas de diferentes lugares, com diferentes tradições, costumes, padrões e estilos de vida. Sua falta de coesão $e$ ausência de normas grupais ameaçava a ordem estabelecida. O medo da poluição, da infecção anômica e o rebaixamento do status do grupo levavam os moradores antigos a recorrer à fofoca, que funcionava como eficiente mecanismo de preservação de sua identidade grupal. A censura tinha função integradora, pois servia para manter as opinióes e crenças coletivas quanto ao que era 
Ao frequentarem um curso de modelo, as pré-adolescentes adquiriam novos conhecimentos que as levavam a buscar uma nova forma de vestir e de se comportar. Entretanto, elas continuavam morando no mesmo local. Assim, tinham que permanecer obedecendo às regras da vizinhança. Como a nãoobservância das normas grupais "pode enfraquecer sua própria defesa contra o desejo de romper as normas prescritas" (Elias; Scotson, 2000:49), para evitar prejuízos para o grupo, seus membros sentem-se compelidos a repelir aquilo que vivenciam como ameaça à sua coesão. Em razão dessa ameaça, a circulação de fofocas depreciativas constitui uma forma de controle de impulsos individuais dentro do grupo. Devido às fofocas, vindas especialmente das pessoas mais velhas, o local representado como ideal para morar, com o qual as pré-adolescentes demonstraram maior afinidade foi o centro da cidade, como a praça principal e o Calçadão, como ressalta Helena:

Gostaria de morar mais no centro, no calçadão e na praça, que não têm muito vizinho. (...) As pessoas mais velhas falam mal dos outros. Elas ficam olhando a gente da janela. Se você traz uma pessoa na sua casa eles ficam perguntando, quem é a pessoa.

O centro da cidade é percebido como local de prestígio $^{6} e$ anonimato, em que as origens são desconhecidas e os vizinhos não dão conta da vida dos outros. O desejo de anonimato pode se dar em função de uma trajetória de vida em um local marginalizado, já que várias pré-adolescentes moravam na periferia pobre. Ao mesmo tempo em que tinham contato com os grandes centros lançadores de moda e com o universo das

desejável ou não ao grupo. O medo de serem estigmatizados pela fofoca levava os membros do grupo a agir conforme os valores grupais.

6 Enquanto o centro de uma cidade do interior pode ser visto como local de prestígio, o centro de uma cidade metropolitana talvez não seja visto com o mesmo prestígio em função da grande violência ocorrida nesses locais. 
modelos (via televisão e revistas), as pré-adolescentes residiam em uma cidade pequena, cujos contatos eram muito pessoais. Assim, mesmo que houvesse o desejo de acompanhar o estilo de vida das modelos, as pré-adolescentes se sentiam limitadas pela reputação na vizinhança, já que os vizinhos recorriam às fofocas, visando reproduzir valores e assegurar a coesão grupal.

Nos argumentos das pré-adolescentes e de suas mães, ressalta-se também uma vivência religiosa, com participação em grupos de oração e catequese. O que revela uma contradição entre os valores familiares ligados à moral religiosa $e$ as possibilidades que poderão se abrir em decorrência da profissão de modelo, como tirar fotos nuas para revistas masculinas. Por conta dessa moral, as famílias muitas vezes se sentiam incomodadas com as cenas eróticas exibidas na televisão $e$ rejeitavam os conteúdos da mídia que fossem conflitantes com os valores ligados ao pudor.

O "mau exemplo" que as modelos apresentadas na mídia podem oferecer às pré-adolescentes, que ainda não tem muita experiência de vida, é considerado negativo para as famílias, pois divulga um padrão de comportamento que pode ferir a moral familiar na vizinhança. Por isso, uma pré-adolescente que preze sua moral deve tomar cuidado para não se envolver com nada que ameace sua reputação. Conhecendo os perigos da má reputação, as filhas se apropriam e reproduzem os valores morais transmitidos pelos pais, como ressalta Amanda:

eu acho que essas pessoas famosas da televisão são muito vulgares e mostram muito o corpo, e quanto mais a gente mostra, mais as pessoas perdem o interesse em você. Acho que as pessoas têm que se valorizar mais. Às vezes fazem isso até pelo cachê.

A perda de "interesse" na mulher que expõe o seu corpo, à qual Amanda se refere, faz parte de um julgamento que perpassa não só a família e a vizinhança, mas diz respeito especialmente a 
julgamentos masculinos diante da conjugalidade, o que implica uma apropriação, pelas pré-adolescentes, de uma lógica hierárquica que define como as mulheres devem se comportar. Diante desse julgamento, a exposição da nudez - por ser vista como um fator que desclassifica as mulheres - passa a ser vista como algo feio e repudiado pelas pré-adolescentes, como Cíntia que acha "muito feio as pessoas que tiram fotos nuas... acho que não podiam permitir isso". A naturalização dessa lógica, desde a pré-adolescência, contribui fundamentalmente na construção das subjetividades das mulheres, levando-as, frequentemente, a ocupar uma posição de subordinação não só no âmbito da família, mas em diversos setores da sociedade, como ressalta Rocha-Coutinho (1994).

Diante das influências da mídia que destoam dos padrões morais, a família exerce um papel fundamental de filtragem $e$ reorganização dos valores. Afinal, como menciona Cynthia Sarti (1996), é no âmbito da família que o indivíduo estrutura seu mundo simbólico e constrói padrões de comportamento que serão reproduzidos na sociedade. Nas famílias pobres, a preservação de valores "tradicionais" de honestidade, honra e responsabilidade, fortemente perpassados por marcadores de gênero, possibilita a construção de um mapa de referências sobre o qual seus membros se apóiam nas experiências cotidianas e relações sociais. A manutenção da ordem moral, além de reforçar a dignidade familiar, permite a coesão entre seus membros, na medida em que prioriza projetos coletivos em detrimento da afirmação da individualidade.

Em função dos valores familiares, os conteúdos apresentados na mídia não são absorvidos pelas famílias tal qual são apresentados, pois os significados são atribuídos de acordo com os referenciais culturais. Nesse processo, os pais filtram o que a televisão apresenta, traduzindo isso para seus padrões de moralidade e consumo, permitindo que sejam incorporados apenas os aspectos condizentes com seus valores. As roupas das 
filhas constituem aspecto bastante controlado pelos pais, visando preservar os valores que privilegiam. Iasmim comenta:

Minha mãe não deixa eu comprar roupas muito escandalosas... mas eu amo roupas escandalosas! [Sua mãe menciona que, embora sua filha goste] de short muito coladinho e curtinho [ela não gosta de deixá-la usar] roupa muito escandalosa, extravagante, muito curtinha, [pois] fica muito vulgar. [A mãe da Amanda também ressalta que conversa muito com a filha] e ela acaba não se vestindo muito de qualquer jeito. Muita coisa que ela sabe que eu não aceito, ela não usa. Então, eu controlo. Eu falei pra ela: para ser bonita não precisa ser vulgar.

Ao falar sobre o projeto de ser modelo, algumas préadolescentes mencionaram o projeto do casamento, do vestido de noiva, da vida conjugal, dos filhos e da vida profissional. A recorrente referência ao casamento e à constituição familiar, tanto pelas mães quanto pelas meninas, possibilitou-me entender $\mathrm{o}$ motivo da tensão entre a moralidade das famílias $e$ as representações da "vulgaridade" das modelos da televisão. Caso a filha viesse fazer o que as modelos fazem, certamente, ficaria "falada" pela vizinhança e não seria vista como "adequada" para casar-se com um bom "moço de família", contrariando assim o projeto familiar quanto ao casamento.

Os aspectos referentes à moralidade revelam entraves $e$ incompatibilidades entre os valores veiculados pelas modelos apresentadas na mídia $e$ aqueles ligados ao casamento $e$ à constituição do lar. A profissão de modelo, além de veicular uma corporalidade erotizada, aponta para uma construção moderna, na qual o casamento pode não fazer parte ou pode ser vivido de forma muito diferente daquela almejada pelas famílias. Assim, para assegurar um "bom casamento", a honra familiar é algo muito presente, visto que a "vulgaridade" e a conduta inadequada da filha podem ameaçar a moral feminina e levar à exclusão social. 
Mary Del Priore (2005) afirma que o discurso quanto ao recato e pudor feminino no Brasil tornou-se poderoso a partir de 1879, com a criação da cadeira de Clínica Psiquiátrica nos cursos da faculdade de Medicina, os quais possibilitaram "consagrar a ética do bom e do mau comportamento sexual". Nessa ocasião, os médicos examinavam mulheres "suspeitas", cujas vidas amorosas distanciavam dos "bons preceitos" e da higiene desejada pela ordem burguesa que se instalara nos centros urbanos.

Del Priore ressalta que a mulher cuja moral era apreciada deveria ser "naturalmente" frágil, agradável, boa mãe, submissa e doce. Aquela que não tivesse esses atributos era considerada um ser "antinatural". O princípio a ser seguido era que o "instinto materno" anulava o "instinto sexual". Assim, aquelas que revelassem desejo ou prazer sexual deveriam receber tratamentos médicos, já que eram consideradas "anormais". Atualmente, embora a condição feminina na legislação e na sociedade tenha passado por diversas mudanças, essas representações ainda continuam presentes no imaginário popular, mantendo vivos os valores de recato e pudor atrelados ao universo feminino.

A permanência dessas representações contribui para que a profissão de modelo, às vezes, seja vista sob suspeita. Por ser entendida como um obstáculo à constituição de uma família, é vista como uma profissão "não séria". Uma profissão séria seria aquela que não oferece ameaças ao projeto do matrimônio, visto como prioritário na vida das famílias das pré-adolescentes, como ressalta Amanda:

Minha mãe fala: Quero que você estude, pois na profissão de modelo você não pode constituir uma família. E minha mãe fala assim: Eu quero que você constitua uma família, que tenha uma profissão séria.

Por representar um elemento estruturador e mantenedor da ordem social, o casamento é visto como indícios de estabilidade, 
equilibrio e responsabilidade necessários à existência de uma mulher que se "completa" na maternidade. O sentido atribuído ao casamento, ao cuidado com o lar e com a família é transmitido pelos pais e apropriados pelas filhas como destino manifesto da mulher, posicionando-as na trama das relações sociais e de gênero. Em seus relatos, tanto Amanda quanto Bárbara ressaltam o sonho do vestido de noiva:

Quando eu penso no meu futuro, vem na minha mente mesmo é eu vestida de noiva, eu desenhando o meu vestido. (...) Eu quero um vestido discreto, mas também eu não quero um vestido muito apagado, não. (...). Então eu fico imaginando... que vestido que pode ser? Que cor que pode ser? [Bárbara também sorri e comenta que já desenhou as roupas, o bolo e tudo mais para sua festa de 15 anos, como também já desenhou seu vestido de casamento].

Em oposição à profissão de modelo, que é instável e passageira, a constituição de uma família aparece como possibilidade de solução dos problemas cotidianos, pois fornece uma sensação de proteção e segurança (Almeida, 2001). Entre as pré-adolescentes, parece que o sonho de entrar na igreja vestida de noiva tem um significado semelhante ao sonho de fazer sucesso na passarela da moda. "Desfilar" pela "passarela da igreja" e ser admirada pela beleza de suas vestes faz com que "os contos de fadas se mesclam aos contos de fadas tecnológicos" (Silva, 1985:80).

Enquanto as pré-adolescentes se imaginam vivendo a fama e o sucesso das modelos, os pais se preocupam com a possibilidade de suas filhas receberem convites para participar de cenas de erotismo e nudez (algo interditado às suas filhas). Em busca de entender os motivos pelos quais os pais, mesmo vendo as modelos como "prostitutas" $e$ "vulgares", permitiram que as filhas fizessem o curso de manequim e modelo, percebi que algumas mães diziam que tinham matriculado as filhas para que 
ficassem mais desinibidas e conhecessem mais pessoas, já que eram muito tímidas, ou seja, o curso representava uma forma de ampliar o capital social e simbólico, nos termos de Bourdieu.

\section{Considerações finais}

Devido ao distanciamento entre a realidade $e$ as imagens das modelos na mídia, a tentativa das pré-adolescentes de trabalhar como modelo revela ambivalências, contradições $e$ tensões na família e na vizinhança. Especialmente no que se refere à moralidade familiar em virtude das novas exigências $e$ possibilidades, que podem se abrir em função da participação no curso de modelo, mas que são conflitantes com os valores familiares ligados ao casamento. A centralidade da conjugalidade $e$ a ampla valorização da família fazem com que a questão da honra seja muito forte, visto que a "vulgaridade" constitui uma questão ameaçadora à moral feminina. A "conduta inadequada" da filha poderia ferir a honra da família e constituir um mecanismo de exclusão social.

Enquanto o mundo da fama é visto pelas famílias como desprovido de valores como o pudor e a mídia exalta a modelo como "símbolo sexual", as pré-adolescentes frequentam catequese $e$ os pais buscam preservar, nas filhas, valores como o recato, o pudor e a discrição, almejando, para elas, o casamento $e$ a maternidade. $\mathrm{O}$ status preferencialmente considerado como feminino é definido pelo cuidado com o lar, os filhos e o corpo. Ao se apropriarem de uma série de regras e novos conhecimentos, as pré-adolescentes são impossibilitadas de colocá-los em prática.

Apesar do curso não corresponder às expectativas quanto à profissão de modelo por não trazer os resultados imediatamente esperados, bem como o fato de os projetos quanto à profissão de modelo e ao casamento parecerem conflitantes, em certa medida, participar do curso favorece o projeto da conjugalidade, pois 
permite ampliar o capital simbólico e sociall, como destaca a mãe de Gabriela:

Minha filha sempre foi uma menina muito tímida, então eu falei pra ela fazer o curso pra ela ficar assim, mais saidinha, mais desinibida. Aí ela fez e gostou. Ela é muito calada, né? E também pra ela entrosar mais com outras coleguinhas. [A mãe da Eliana ressaltou que frequentar o curso] foi bom porque ela aprendeu a desfilar, (...) conheceu mais gente, né? Antes ela conhecia só as meninas perto de casa, pessoas da família e as colegas da escola, hoje ela conhece muita gente. Ela está muito conhecida hoje. (...) Ela passa na rua e todo mundo a conhece. [Bárbara também ressaltou] Teve uma vez que eu fui à casa da minha colega, uma menina me parou na rua e falou assim: Você desfilou, não desfilou? Ah, eu adorei! Eu gosto... é legal...

Permitir que a filha participasse no curso para que se tornasse mais "desinibida" e conhecesse mais pessoas pode ter conotações mais amplas no jogo das relações de afinidade. Talvez seja por isso que tanto as mães quanto as filhas pesquisadas ressaltaram a satisfação de andar pelas ruas e perceber que suas filhas haviam se tornado mais populares e conhecidas.

Para essas pré-adolescentes residentes em bairros da periferia pobre da cidade, frequentar o curso de modelo pode ser visto como uma "tecnologia de gênero", no sentido atribuído por De Lauretis (1994). A forma como os conteúdos são ministrados reforça atributos de masculinidade e feminilidade. Conforme anunciado por Simone de Beauvoir, "não se nasce mulher, tornase mulher". Mediante a participação no curso de manequim e modelo, as pré-adolescentes se apropriam de um conjunto de valores, técnicas e normas que contribuem para a passagem do universo infantil para o universo das mulheres que se embelezam, cuidam do corpo, aprendem a controlar a corporalidade, os gestos

7 No sentido atribuído por Pierre Bourdieu (2006). 
e as posturas. $\mathrm{O}$ curso de manequim e modelo, muito mais que ensinar às pré-adolescentes os aspectos técnicos exigidos na profissão, constitui um tipo de pedagogia cultural que reproduz valores e saberes, fornecendo modelos de conduta e estilos de vida, uma vez que veiculam elementos que permitem construir a feminilidade mediante técnicas, expressões corporais e regras de comportamento.

$\mathrm{O}$ investimento para que a filha esteja em condições de concorrer nas passarelas possibilita que o corpo e a aparência, como ressalta Goldemberg (2006), deixem de pertencer ao domínio da natureza para serem produzidos, trabalhados $e$ cultivados na e pela cultura, tornando-se um verdadeiro capital. Como lembra Goellner (2003:28), "o corpo é provisório, mutável e mutante, suscetível a inúmeras intervenções" que permite produzir e reproduzir discursos e normas de comportamento. A construção cultural do corpo revela, assim, a centralidade que a categoria corpo adquiriu para as pré-adolescentes, a partir da participação no curso.

O curso possibilita a construção de "representações de gênero como posições sociais que trazem consigo significados diferenciais" (Lauretis, 1994:212), pois a profissão de modelo exige o domínio de uma série de códigos e habilidades aos quais essas meninas não possuem acesso, devido a suas condições de classe. Mediante a participação no curso, molda-se uma corporalidade delicada, um gestual polido e transmitem-se regras de etiqueta que permitem ampliar o capital simbólico. Além disso, em função do local que as famílias ocupam nas redes de sociabilidade, frequentar o curso pode ser uma forma de buscar maior projeção e respaldo social via promoção da filha. Desfilar em shoppings e clubes, transitar por ambientes frequentados pela elite local, ser admirada e aplaudida constituem oportunidade ímpar de apresentar a filha à sociedade e ampliar as redes de sociabilidade e o capital simbólico, o que pode ser visto como um investimento familiar. 
Considerando a distância entre o sonho de ser uma modelo famosa no país e no exterior, bem como a impossibilidade da concretização desse sonho, vivenciar esse destaque no plano do micro ambiente já satisfaz. A participação no curso pode ser vista como "bem" ou "moeda de troca" que permite adquirir certas competências e transitar em outros espaços que não são dados pela condição de classe das pré-adolescentes. Adquirir as habilidades e técnicas corporais, bem como tornar a filha socialmente conhecida, um dos projetos sociais envolvidos no curso, pode ser uma forma de ampliar os contatos e, quem sabe, conseguir mais tarde um bom casamento.

\section{Referências bibliográficas}

ALMEIDA, Heloisa Buarque de. "Muitas coisas mais": telenovela, consumo e gênero. Tese de doutorado, Antropologia, Unicamp, 2001.

BELELI, Iara. Corpo e identidade na propaganda. Revista Estudos Feministas (22), Florianópolis-SC, 2007, pp.193-215.

BONADIO, Maria Claudia. Dignidade, celibato e bom comportamento: relatos sobre a profissão de modelo e manequim no Brasil dos anos 1960. Cadernos Pagu (22), Núcleo de Estudos de Gênero Pagu/Unicamp, 2004, pp.47-81.

BouRdiEU, Pierre. O Poder Simbólico. Rio de Janeiro, Bertrand Brasil, 2006.

BUTLER, Judith. Regulaciones de género. Revista de estudios de género La ventana (23), Guadalajara, México, 2005, pp.7-35.

Del PRIORE, Mary Lucy Murray. História do amor no Brasil. São Paulo, Contexto, 2005.

ELIAS, Norbert e SCOTSON, John L. Os estabelecidos e os Outsiders. Sociologia das relações de poder a partir de uma pequena comunidade. Rio de Janeiro, Jorge Zahar, 2000.

GOELLNER, Silvana Vilodre. A produção cultural do corpo. In: GoELLNER, S. V.; LOURO, Guacira Lopes; NECKEL, Jane Felipe. (orgs.) Corpo, 
gênero e sexualidade: um debate contemporâneo na educação. Petrópolis-RJ, Vozes, 2003, pp.28-40.

GOLDENBERG, Mirian. O corpo como capital: para compreender a cultura brasileira. Arquivos em Movimento (02), Rio de Janeiro, 2006, pp.19.

LAURETIS, Teresa de. A tecnologia do gênero. In: HollandA, Heloisa Buarque de. (org.) Tendências e impasses: o feminismo como crítica da cultura. Rio de Janeiro, Rocco, 1994, pp.206-242.

MeYROWITZ, Joshua. No sense of place. New York, Oxford University Press, 1986.

RocHA, Everardo. Magia e capitalismo. São Paulo, Brasiliense, 1995.

RochA-CouTinHO, Maria Lúcia. Tecendo por trás dos panos: a mulher brasileira nas relações familiares. Rio de Janeiro, Rocco, 1994.

SARTI, Cynthia Andersen. A família como espelho: um estudo sobre a moral dos pobres. Campinas-SP, Autores Associados, 1996.

SILVA, Alice Inês Oliveira e. Rendas, babados, bilros e crochês: a construção social da mulher de prendas domésticas. Dissertação de mestrado, Antropologia, Unicamp, 1985.

Wolf, Naomi. O mito da beleza. Rio de Janeiro, Rocco, 1991. 